\title{
TEKNIK DAN FINANSIAL BUDIDAYA RUMPUT LAUT (Eucheuma cottonii) DENGAN METODE JALUR DI KELOMPOK TANI MITRA BAHARI DESA TANJUNG PADEMAWU PAMEKASAN MADURA
}

\author{
Ramarsa Hidayatulbaroroh \\ Jurusan Teknologi Pengelolaan Sumberdaya Perairan, \\ Sekolah Tinggi Perikanan, Jakarta. \\ Email: ramarsa.hidayat@gmail.com
}

\begin{abstract}
Abstrak - Berbagai jenis rumput laut ada di Indonesia. Dari jenis-jenis tersebut, ada beberapa jenis rumput laut bernilai ekonomi yang telah diperdagangkan sejak lama. Salah satu jenis rumput laut yang memiliki permintaan tinggi di pasar dunia adalah penghasil karaginan atau yang disebut karaginofit. Rumput laut karaginofit, yang paling popular adalah Eucheuma cottonii atau yang sering disebut Kappaphycus alvarezii. Pemanfaatan jenis rumput laut tersebut sangat luas yaitu dari sektor pangan maupun non-pangan. Oleh karena itu, tidak mengherankan apabila seiring berjalannya waktu, permintaannya semakin meningkat seiring teknologi dan kebutuhan manusia yang juga semakin tinggi. Sehingga pengetahuan akan teknis budidaya maupun finansial rumput laut menjadi hal yang patut dikuasai.
\end{abstract}

Dari hasil penelitian yang dilakukan diperoleh data bahwa tempat melakukan penelitian yaitu KUB Mitra Bahari ternyata memiliki usaha lokasi pertanian rumput laut yang kurang layak misalnya dari segi kualitas air, suhu, dan salinitas sehingga menghasilkan pertumbuhan kurang dari $3 \%$. Disamping itu terdapat predator seperti ikan baronang dan penyakit ice-ice. Sedangkan dari analisis finansial diperoleh pendapatan sebesar Rp 275.625.595,00 dengan nilai rugi laba sebesar $R p$ 62.852.382,00. B/C ratio sebesar 1,3 dan BEP sebesar $R p$ 7.290/kg. payback period selama 2 tahun 1 bulan 6 hari dan Rol sebesar $40 \%$

Kata kunci: rumput laut, Eucheuma cottonii, produksi, analisis finansial

\begin{abstract}
There is many variety of seaweed in Indonesia. Among them there's a lot of seaweed with high economic value. One of a kind with high value and high demand from around the world is Eucheuma cottonii or Kappaphycus alvarezii. Eucheuma cottonii contains high karaginan which is imprortant for human health. Seaweed has a lot of benefit for food or others, so that we has to improve our knowledge about seaweed especially Eucheuma cottonii.
\end{abstract}

From the research at KUB Mitra Bahari, their location too produce seaweed is not a perfect place such as their water quality, temperature, and salinity. This factor caused their seaweed growth less than 3\%. Beside that, there is a predator like Baronang fish and a disease that attack the seaweed such as ice-ice. From financial analiysis, their income is Rp 275.625.595,00, with profit and loss ratio $R p$ 62.852.382,00. B/C ratio is 1,3 and BEP Rp 7.290/kgs. And their payback period is 2 years 1 month and 6 days. Their Rol are $40 \%$

Keyword: seaweed, Eucheuma cottonii, production, financial analysis

\section{PENDAHULUAN}

Kekayaan sumber daya hayati laut (flora dan fauna) Indonesia tidak diragukan lagi, mengingat tiga per empat wilayahnya terdiri dari lautan, dengan panjang pantai sekitar $81.000 \mathrm{~km}$ (Parenrengi dkk., 2012). Luas efektif perairan untuk pengembangan budidaya rumput laut diperkirakan mencapai
384.727 ha $(4,6 \%$ dari luas areal potensial budidaya laut seluas 8.363.501 ha) dengan sumberdaya rumput laut \pm 555 jenis (Surono $d k k ., 2009$ ).

Salah satu jenis rumput laut karaginofit (mengandung karaginan) yaitu Eucheuma cottonii yang kandungannya telah banyak dimanfaatkan di industri makanan dan non- 
makanan seperti industri farmasi, kosmetik, percetakan dan tekstil (Bono dkk., 2014). Selain itu, manfaat lain rumput laut yaitu mampu mengurangi pelepasan karbondioksida sehingga membantu mencegah percepatan pemanasan global (Erlania dkk., 2013) meskipun serapan karbon bervariasi pada setiap musim tanam (Erlania dan Radiarsa, 2014).

Permintaan rumput laut dapat dilihat dari total ekspor rumput laut Indonesia tahun 2014 mencapai USD 226,23 juta. Nilai ini mengalami peningkatan sebesar $39,25 \%$ dari tahun 2013 sebesar USD 162,45 juta. Sementara ekspor rumput laut pada periode Januari-Mei 2015 mencapai USD 75,73 juta atau menurun $12,88 \%$. Trend ekspor ke dunia 2010-2014 meningkatan sebesar $11,06 \%$. Lima negara tujuan ekspor terbesar rumput laut adalah China dengan pangsa ekspor $72.06 \%$; Filipina dengan pangsa $5,82 \%$, Chile $(4,89 \%)$; Korea $(4,39 \%)$ dan Vietnam $(2,05 \%)$. Dari total ekspor rumput laut dunia, Indonesia mampu menjadi pemasok utama rumput laut dunia dengan pangsa sebesar $26,50 \%$ dari total USD 1,09 miliar permintaan dunia, disusul oleh Chile $16,73 \%$, Korea Selatan 16,06\%, Tiongkok $7,98 \%$ dan Filipina sebesar 5,77\% (DJPen, 2015).

Mengingat tingginya permintaan rumput laut untuk kebutuhan berbagai industri dalam dan luar negeri, maka upaya penyediaan bahan baku yang berkualitas dan berkesinambungan menjadi sangat penting. Data dari Kementerian Kelautan dan Perikanan (KKP) mencatat produksi rumput laut Indonesia pada 2015 mencapai 10.335.000 ton basah atau jika dikonversi menjadi 1.033.500 ton kering (Nwd dan Dny, 2016). Hasil ini ditargetkan meningkat menjadi 19,5 juta ton pada 2019 (Gdn dan Dny, 2016). Namun, sumber daya rumput laut di alam mulai berkurang dan terbatas sehingga salah satu upaya yang harus dilakukan adalah dengan melakukan budidaya untuk menyokong kebutuhan rumput laut (Parenrengi $d k k$., 2012).

Budidaya rumput laut khususnya kelompok karaginofit pertama kali dibudidayakan di Bali dengan menggunakan bibit yang berasal dari Tambalang- Filipina sebagai negara yang pertama mengekspor jenis rumput laut jenis ini (Parenrengi $d k k$. 2012). Sekarang, lokasi budidaya rumput laut E.cottonii sudah tersebar di berbagai perairan pantai Indonesia. Salah satunya adalah perairan pantai Selatan Madura (Anggadiredja $d k k ., 2006)$.

Pada tahun 2015, panen rumput laut musim tersebut mencapai 500 ribu ton di Kabupaten Sumenep, Madura (Bahri dan Esa, 2015). Sedangkan Madura memiliki 2 Kabupaten utama penghasil rumput laut $E$. cottonii, yaitu Kabupaten Sumenep dan Kabupaten Pemakasan. Kabupaten Pamekasan sendiri pernah meraih penghargaan Adi Bakti Minabahari tingkat nasional dibidang pembudidayaan rumput laut pada tahun 2011.

Berdasarkan uraian di atas, maka pada praktik integrasi penulis mengambil judul "Teknik dan Finansial Budidaya Rumput Laut (Eucheuma cottonii) dengan Metode Jalur di Kelompok Tani Mitra Bahari Desa Tanjung Pademawu Pamekasan Madura".

\section{KAJIAN PUSTAKA}

\section{Biologi Rumput Laut}

Ganggang coklat dan merah merupakan kelas rumput laut utama yang memiliki nilai ekonomis penting di Indonesia. Sebagai contoh adalah genus Eucheuma, Kappaphycus, Hypnea, dan Glacilaria dari kelas ganggang merah, serta Sargassum dari kelas ganggang coklat. Eucheuma, Kappaphycus, Hypnea menghasilkan metabolit primer senyawa hidrokoloid yang disebut karaginan sehingga dikenal sebagai karaginofit. Glacilaria menghasilkan senyawa hidrokoloid yang disebut agar sehingga dikenal sebagai agarofit. Sedangkan Sargassum menghasilkan senyawa hidokoloid yang disebut alginat sehingga dikenal sebagai alginofit (Parenrengi dkk., 2012).

\section{Taksonomi}

Menurut Anggadireja dkk. (2006) rumput laut komersial dikelompokkan menjadi lima, yaitu Eucheuma, Hypnea, Glacilaria, Gelidium, dan Sargassum. Taksonomi masing-masing kelompok diuraikan sebagai berikut:
a. Eucheuma

$\begin{array}{ll}\text { Divisio } & \text { : Rhoodophyta } \\ \text { Kelas } & \text { : Rhoodophyceae } \\ \text { Bangsa } & \text { : Gigartinales } \\ \text { Suku } & \text { : Solierisceae } \\ \text { Marga } & \text { : Eucheuma }\end{array}$


Jenis : Eucheuma spinossum Eucheuma cottonii

b. Hypnea

$\begin{array}{ll}\text { Divisio } & \text { : Rhoodophyta } \\ \text { Kelas } & : \text { Rhooodophyceae } \\ \text { Bangsa } & : \text { Gigartinales } \\ \text { Suku } & : \text { Solierisceae } \\ \text { Marga } & : \text { Hypnea } \\ \text { Jenis } & \text { : Hypnea sp. }\end{array}$

c. Gracilaria

$\begin{array}{ll}\text { Divisio } & \text { : Rhoodophyta } \\ \text { Kelas } & \text { : Rhoodophyceae } \\ \text { Bangsa } & : \text { Gigartinales } \\ \text { Suku } & : \text { Gracilariaceae } \\ \text { Marga } & : \text { Gracilaria } \\ \text { Jenis } & \text { : Gracilaria gigas } \\ & \text { Gracilaria verrucosa } \\ & \text { Gracilaria lichenoides }\end{array}$

d. Gelidium

$\begin{array}{ll}\text { Divisio } & : \text { Rhoodophyta } \\ \text { Kelas } & : \text { Rhoodophyceae } \\ \text { Bangsa } & : \text { Gilidiales } \\ \text { Suku } & : \text { Gilidiaceae } \\ \text { Marga } & : \text { Gelidium } \\ \text { Jenis } & : \text { Gelidium sp. }\end{array}$

e. Sargassum

$\begin{array}{ll}\text { Divisio } & \text { : Rhoodophyta } \\ \text { Kelas } & \text { : Phaeophyceae } \\ \text { Bangsa } & \text { : Fucales } \\ \text { Suku } & \text { : Sargassaceae } \\ \text { Marga } & \text { : Sargassum } \\ \text { Jenis } & \text { : Sargassum polyfolium } \\ & \text { Sargassum crassifolium }\end{array}$

\section{Morphologi}

Rumput laut merupakan salah satu jenis tanaman tingkat rendah yang termasuk dalam golongan ganggang yang hidup dalam air laut serta tidak mempunyai batang dan daun sejati sehingga disebut Thallophyta (Sunaryat, dkk. 2008)

\section{a. E. cottonii}

Yaitu thallus silindris, permukaan licin, cartilageneus (menyerupai tulang rawan/muda). Serta berwarna terang, hijau olive dan coklat kemerahan. Karena perbedaan warna tersebut, rumput laut ini dikelompokkan menjadi varietas coklat dan varietas hijau (Prenrengi, dkk. 2012)

b. E. spinosum

Morfologinya mirip dengan E. cottonii, namun memiliki duri yang tumbuh berderet melingkari thallus dengan interval yang bervariasi. Percabangan berlawanan, berseling dan timbul teratur pada daerah deretan duri antar ruas. Ujung percabangan meruncing dan mudah melekat pada substrat. Warna coklat tua, hijau kekuningan atau kuning ungu.

c. E. edule

Thallus Eucheuma edule berbentuk silindris, permukaaan licin, dan berwarna hijau, kuning atau coklat hijau. Percabangan berseling dan thallus ditumbuhi nodulus. Rumpun yang dimiliki kokoh namun tidak rimbun

d. G. gigas

Thallus G. Gigas lebih besar dari Gracilaria lainnya yaitu mencapai $30 \mathrm{~cm}$ dengan diameter 0,5-22 mm, berbentuk silindris, agak kasar dan kaku, serta memiliki warna hijau-kuning atau hijau. Percabangan cenderung memusat ke pangkal, memanjang, berselang seling, berulang-ulang searah dan ujungnya runcing

e. G. verrucosa

Ciri yang dimiliki $G$. verrucosa yaitu thallus silindris, licin, dan berwarna kuning-coklat atau kuning-hijau. Percabangan berseling tidak beraturan, memusat ke arah pangkal. Cabang lateral memanjang menyerupai rambut, ukuran panjang sekitar $25 \mathrm{~cm}$ dengan diemeter thallus $0,5-1,5 \mathrm{~mm}$

f. S. crassifolium

S. crassifolium memiliki thallus pipih, licin, batang utama bulat agak kasar, dan holdfast (bagian yang digunakan untuk melekat berbentuk cakram). Cabang pertama timbul pada bagian pangkal sekitar $1 \mathrm{~cm}$ dari holdfast. Percabangan berselang-seling secara teratur. Bentuk daun oval atau memanjang, berukuran $40 \times 10 \mathrm{~mm}$. Tepi daun bergerigi jarang, berombak, dan ujung melengkung atau meruncing. Vesicle (gelembung seperti buah) berbentuk lonjong, ujung meruncing, berukuran $7 \times 1,5 \mathrm{~mm}$ dan agak pipih

\section{Sistem Reproduksi}

Parenrengi dkk. (2012) menguraikan perkembangan rumput laut dikenal dalam dua bentuk reproduksi yaitu dengan seksual (generatif) dan aseksual (vegetatif).

a. Generatif

Rahardjo dkk. (2008) dan Parenrengi dkk. (2012) menjelaskan bahwa peristiwa perbanyakan secara generatif rumput laut yang diploid (2n) menghasilkan spora yang haploid (n). Spora ini kemudian berubah menjadi 2 jenis yaitu jantan dan betina yang haploid (n). 
Selanjutnya rumput laut jantan akan menghasilkan sperma dan rumput laut betina akan menghasilkan sel telur. Anggadiredja dkk. (2006) menambahkan bahwa pertemuan dua gamet membentuk zygot dan berkembang menjadi sporofit. Individu baru inilah yang mengeluarkan spora dan berkembang melalui pembelahan dalam sporogenesis menjadi gametofit

b. Vegetatif

Perbanyakan secara vegetatif berlangsung tanpa perkawinan, setiap rumput laut yang dipotong akan tumbuh menjadi rumput laut muda yang memiliki sifat (genotip) seperti induknya (Rahardjo $d k k ., 2008)$. Dapat juga melalui cara setek, yaitu potongan thallus yang kemudian tumbuh menjadi tanaman baru (Anggadiredja $d k k$., 2006) dengan syarat dilakukan pada cabang-cabang thallus yang muda, masih segar, warna cerah dan memiliki percabangan yang rimbun serta terbebas dari penyakit (Parenrengi $d k k ., 2012)$.

\section{Habitat dan Sebaran}

Rumput laut E. cottonii asal mulanya berasal dari perairan Kalimantan kemudian dikembangkan ke berbagai negara sebagai tanaman budidaya (Doty,1970 dalam Parenrengi dkk., 2012). Namun, pada saat pertama kali budidaya rumput laut tersebut di Bali menggunakan bibit dari TambalangFilipina (Parenrengi $d k k$., 2012). Di alam, pertumbuhannya melekat pada substrat dengan alat perekat berbentuk cakram (Surono dkk., 2009). Rumput laut memerlukan sinar matahari untuk pertumbuhannya, sehingga hanya mungkin hidup pada kedalaman sejauh sinar matahari masih mampu mencapainya (fotik) (Parenrengi dkk., 2012).

Wilayah sebaran rumput laut yang tumbuh alami (wild stock) terdapat di hampir seluruh perairan dangkal Perairan Indonesia yang mempunyai rataan terumbu karang. Sedangkan lokasi budidaya E. cottonii tersebar di perairan pantai di beberapa pantai Kepulauan Riau, Bangka-Belitung, Lampung Selatan, Pulau Panjang (Banten), Pulau Seribu, Karimun Jawa (Jawa Tengah), Selatan Madura, Nusa Dua, Nusa Lembongan dan Nusa Penida (Bali), Lombok Barat, Lombok Timur (Teluk Ekas), Sumbawa, Larantuka, Teluk Maumere, Sumba, Alor, Kupang, P. Rote, Sulawesi Utara, Gorontalo, Bualemo, Bone Balango,
Samaringa (Sulawesi tengah), Sulawesi Tenggara, Jeneponto, Takalar, Selayar, Sinjai, dan Pangkep (Sulawesi Selatan), Seram, Ambon, dan Aru (Maluku), Biak, serta Sorong (Anggadiredja dkk., 2006).

Anggadiredja dkk.(2006) menguraikan bahwa $G$. gigas tumbuh di rataan terumbu karang dengan air jernih, arus cukup, dan salinitas ideal 20-28 g/l. Glacilaria dapat dibudidayakan di laut yang dekat muara sungai. Di samping itu, Glacilaria juga dapat dibudidayakan secara luas di tambak-tambak yang dapat diatur kondisi salinitas airnya antara 15-25 g/l.

\section{Kandungan dan Kegunaan}

Beberapa publikasi menyebutkan bahwa rumput laut banyak mengandung mineral penting untuk kesehatan tubuh. Kandungan mineral pada rumput laut (ganggang merah dan coklat) diuraikan Sunaryat dkk. (2008) dalam Tabel 1

Tabel 1. Kandungan Mineral

\begin{tabular}{|c|c|c|}
\hline \multirow[t]{2}{*}{$\begin{array}{l}\text { Jenis } \\
\text { mineral }\end{array}$} & \multicolumn{2}{|c|}{$\begin{array}{l}\text { Kandungan dalam \% berat } \\
\text { kering }\end{array}$} \\
\hline & $\begin{array}{l}\text { Ganggang } \\
\text { merah }\end{array}$ & $\begin{array}{l}\text { Ganggang } \\
\text { coklat }\end{array}$ \\
\hline Khlor & 1 & 9 \\
\hline Kalium & 1 & 6 \\
\hline Magnesium & 0 & 1 \\
\hline Belerang & 1 & 0 \\
\hline Silikon & 0 & 0 \\
\hline Fosfor & 0 & 0 \\
\hline Kalsium & 0 & 0 \\
\hline Besi & 0 & 0 \\
\hline Iodium & 0 & 0 \\
\hline Bronze & 0 & $0,03-0,14$ \\
\hline Natrium & 1 & 2 \\
\hline
\end{tabular}

Sebagi sumber gizi, rumput laut memiliki kandungan karbohidrat (gula atau vegetable gum), protein, sedikit lemak, dan abu yang sebagian besar merupakan senyawa garam natrium dan kalium. Selain itu, rumput laut juga mengandung vitamin-vitamin seperti vitamin A, B1, B2, B6, B12, dan C, betakaroten (Anggadiredja dkk., 2006).

Kegunaan rumput laut terkait dalam berbagai bidang. $\mathrm{Di}$ bidang pengobatan, beragam rumput laut telah banyak digunakan untuk pengobatan berbagai jenis penyakit (antipiretik, obat cacingan, bronchitis, asma, batuk, hemorrhoids, mengatasi bisul, mimisan, kekurangan iodium, urinaria (Anggadiredja $d k k ., 2006$ ). Sunaryat $d k k$. (2008) menambahkan bahwa rumput laut dapat mencegah kanker usus. Selain itu, 
dibidang industri, karaginan digunakan sebagai bahan penstabil, pengemulsi, pembentuk gel, pengental, pensuspensi, palapis daging, farmasi, kosmetik, keramik serta berbagai makanan. Anggadiredja $d k k$. (2006) melanjutkan bahwa selain karaginan, agar banyak digunakan pada industri farmasi, kosmetik, makanan dan minuman, cetakan gigi, kultur jaringan, dan foto grafis. Sedangkan alginat digunakan pada industri makanan atau minuman, cat, kertas, foto grafis, tekstil dan farmasi

\section{Pemilihan Lokasi}

Pemilihan dan penentuan lokasi lahan budidaya rumput laut harus didasarkan pertimbangan ekologis (arus, suhu, dasar perairan, kedalaman, salinitas, kecerahan, ketersediaaan bibit, dan keberadaan organisme pengganggu), resiko (keterlindungan, keamanan lokasi, konflik kepentingan, dan peraturan/perundangundangan), higienis (keberadaan pollutan/bahan cemaran, industri dan rumah tangga) dan sosio-ekonomi (keterjangakauan lokasi, tenaga kerja, sarana/prasarana, dan kondisi sosial masyarakat) (Parenrengi $d k k$., 2012). Berikut faktor-faktor pemilihan lokasi yang harus diperhatikan:

\section{a. Faktor Ekologis}

Penilaian ekologis dapat dilakukan melalui pendekatan indikator fisika, kimia, dan biologi suatu perairan. Parameter fisika yang ideal antara lain kecepatan arus 20-40 cm/detik, dasar perairan berupa pecahan karang dan pasir kasar, kedalaman 2-15 m (untuk metode long line), dan nilai kecerahan 2-5 m. Sedangkan untuk paremeter kimia yang ideal yaitu suhu $20-28{ }^{0} \mathrm{C}$ dengan nilai $\mathrm{pH} \quad 7,3-8,2$ (Parenrengi dkk.,2012), salinitas 28-34 g/l, perairan subur dan bebas jangkauan pencemaran (Rahardjo $d k k ., 2008)$.

b. Faktor resiko

Faktor resiko yang harus dipertimbangkan meliputi faktor keterlindungan, keamanan lokasi, dan faktor sosial (Surono dkk., 2009) serta konflik kepentingan dan aspek peraturan dan perundang-undangan Parenrengi $d k k$. (2012). Setiap faktor diuraikan sebagai berikut:

- Keterlindungan
Lokasi yang terlindung dari angina dan gelombang besar diperlukan untuk menghindari kerusakan sarana dan tumbuhan rumput laut itu sendiri. Biasanya lokasi dengan kriteria tersebut diperoleh di perairan teluk atau perairan terbuka tetapi terlindung (ada penghalang atau pulau disepannya)(Surono,dkk. 2009)

- Keamanan

Pencurian dan sabotase memiliki peluang terjadi, sehingga pengamanan secara individual maupun kelompok harus dilakukan. Pelaku usaha sebaiknya berupaya menjalin hubungan baik dengan masyarakat sekitar (Parenrengi, dkk. 2012)

- Konflik kepentingan

Kegiatan perikanan (penangkapan ikan, pengumpul ikan hias, pemasangan bubu, bagan) dan kegiatan nonperikanan (pariwisata, perhubungan laut, industri, taman nasional laut) dapat berpengaruh negatif terhadap aktivitas rumput laut (Parenrengi dkk. 2012).

- Aspek peraturan dan perundang undangan

Pemilihan lokasi harus tidak bertentangan dengan peraturan pemerintah dan mengikuti Rencana Umum Tata Ruang yang telah ditetapkan Pemerintah Daerah. Informasi tata ruang wilayah umumnya tersedia pada instansi pemerintah yang terkait seperti Dinas Tata Ruang dan Dinas Kelautan dan Perikanan setempat.

- Faktor Higienis

Keamanan pangan merupakan hal yang harus diperhatikan dalam memproduksi bahan dasar ataupun bahan jadi khususnya untuk keperluan konsumsi. Pemilihan lokasi harus bebas cemaran limbah rumah tangga maupun industri, sampah, hingga lumpur karena rumput laut mampu menyerap polutan (seperti logam berat) yang akhirnya terakumulasi dalam jaringan tanaman. Polutan yang sudah terserap sulit dipisahkan meskipun melalui ekstraksi sehingga dapat terbawa hingga ke produk industri (Parenrengi dkk., 2012).

- Faktor sosio-ekonomi

Tenaga kerja yang akan ditempatkan di lapangan sebaiknya dipilih yang bertempat tinggal berdekatan dengan lokasi budidaya dan memiliki kemauan 
bekerja (Puja dkk., 2008). Penggunaan tenaga lokal dapat menghemat biaya produksi, membuka kesempatan kerja, mempermudah kegiatan monitong dan penjagaan keamanan. Biaya pengangkutan sarana, bibit, dan hasil panen juga perlu dipertimbangkan. Jarak maksimum pengangkutan yang direkomendasikan adalah $1 \mathrm{~km}$ (Surono dkk., 2009).

\section{Pengadaan dan Pemilihan Bibit}

Bibit yang digunakan adalah tanaman muda hasil budidaya di daerah setempat atau dari daerah luar (Puja dkk., 2008). Bibit dapat diperoleh dari tanaman rumput laut yang tumbuh secara alami, budidaya, melalui kultur jaringan, protoplas, dan spora (Parenrengi dkk., 2012). Untuk memperoleh bibit yang unggul, dapat diterapkan seleksi pada bibit. Bibit yang berasal dari seleksi dan kultur jaringan memiliki keunggulan masingmasing. Bibit hasil seleksi memiliki pertumbuhan yang lebih tinggi dibandingkan bibit kultur jaringan. Sedangkan bibit kultur jaringan memiliki kandungan, rendemen, dan gel strength yang lebih baik (Basith, 2014 dan Trawanda dkk., 2014). Namun bibit yang berasal dari perbanyakan vegetatif melalui stek yang berulang menyebabkan penurunan keragaman genetik yang berakibat menurunnya kecepatan tumbuh, rendeman karaginan dan kekuatan gel menurun (Sulistiani dan Yani, 2014).

Bibit yang akan ditanam sebaiknya dikemas supaya tidak mengalami kerusakan. Pengemasan dilakukan dengan memasukan bibit ke dalam kantong plastik besar yang telah dilubangi sebagai aerasi. Selanjutnya, plastik dimasukan ke dalam kardus/karton dengan jumlah tumpukan maksimum 3 tumpuk. Kepadatan harus diperhatikan agar bibit tetap memiliki ruang udara dan tetap dalam keadaan lembab meski tidak sampai membasahi kardus/karton (Anggadiredja dkk., 2006).

Apabila setiba di lokasi tidak bisa dilakukan penanaman segera, sebaiknya bibit rumput laut dikeluarkan dari kantong plastik dan disiram air laut. Bibit rumput laut jangan direndam di dalam wadah karena akan mengeluarkan lendir (mucus), kemudian membusuk dan mati. Cara lain yang dapat dilakukan dengan memasukkan bibit ke dalam jarring plastik, kemudian direndam di dalam laut. Dengan cara ini, lendir yang keluar langsung hanyut ke dalam air laut sehingga tidak sempat merusak bibit (Anggadiredja dkk., 2006).

\section{Pengikatan dan Penanaman Bibit}

Menurut SNI (7673:2:2011) pengikatan bibit dilakukan dengan cara simpul pita dan sedikit longgar. Pengikatan dilakukan di darat, tempat teduh dan bersih dengan menjaga bibit dalam keadaan basah dan lembab. Waktu pengikatan sebaiknya tidak lebih dari 4 jam. Menurut Parenrengi dkk. (2012) menambahkan bahwa terdapat dua metode pengikatan bibit yaitu loop pendek dan loop panjang. Pada loop pendek, pergerakan bibit lebih kaku dibandingkan dengan loop panjang. Namun loop panjang lebih mudah terbelit jika kondisi arus relative besar meskipun mudah dalam pengikatannya. Setelah bibit diikat, maka bibit harus segera ditanam.

\section{Pemeliharaan}

Perawatan harus dilakukan setiap hari untuk membersihkan tanaman dari tumbuhan pengganggu dan menyulam tanaman yang mati dan terlepas (Surono dkk., 2009). Khusus untuk kegiatan penyulaman, hanya dilakukan pada minggu pertama setelah rumput laut ditanam (Runtuboy dkk., 2008). Penyulaman perlu dilakukan agar jumlah tanaman pada setiap tali ris tidak berkurang. Kerusakan tanaman dapat disebabkan oleh gelombang besar atau dimakan binatang herbivor, seperti baronang dan penyu. Umumnya, serangan akan berkurang bila tanaman berada lebih ke tengah dan jauh dari karang hidup (Anggadiredja dkk.,2006). Membersihkan lumpur dan kotoran perlu dilakukan karena lumpur yang melekat akan menyebabkan tanaman mudah terserang beberapa jenis cacing atau nematoda dan munculnya gejala ice-ice. Lumpur akan melekat pada tanaman bila pergerakan air kurang. Hal ini biasanya terjadi pada musim kurang angin dan lokasi budidaya terlindung. Sehingga tali rumput laut harus rajin digoyang-goyang agar lumpur yang melekat terlepas (Anggadiredja dkk., 2006)

\section{Monitoring Pertumbuhan}

Salah satu cara untuk memonitor pertumbuhan adalah melalui sampling. Sampling dilakukan untuk mengetahui pertumbuhan rumput laut yang ditanam (Runtuboy dkk., 2008) dan menjadi acuan dalam memprediksi produksi rumput laut (Anggadiredja dkk., 2006). Menurut Runtuboy dkk. (2008) sampling pertama 
dilakukan pada saat bibit akan ditanam untuk mengetahui berat awal. Sampling kedua dilakukan setelah tanaman berumur tiga minggu. Sedangkan sampling ketiga dilakukan pada saat panen. Sedangkan Surono dkk. (2009) menyarankan sampling dilakukan setiap 2 minggu sekali. Hal tersebut berbeda dengan pendapat Anggadiredja dkk. (2006) bahwa sampling sebaiknya dilakukan satu kali dalam seminggu. Cara sampling menurut Anggadiredja dkk. (2006) meliputi:

a. Timbang berat tanaman pada pertama kali sampling

b. Timbang kembali tanaman yang sama pada hari ke 14, kemudian hitung laju pertumbuhannya. Hal ini dilakukan setiap 7 hari.

Laju pertumbuhan rata-rata minimal rumput laut adalah $>3 \%$. Perlakuan seleksi massal mampu meningkatkan laju pertumbuhan harian, memperpanjang thallus, serta meningkatkan kerimbunan cabang (Fadilah, 2016). Sedangkan untuk aplikasi ekstrak $S$. aquifolium tidak berpengaruh nyata terhadap pertumbuhan (Akbar dkk., 2016).

\section{Monitoring Kualitas Air}

a. Faktor fisika

- Kedalaman perairan berpatokan pada surut terendah dengan tingkat optimum tergantung dari metode budidaya yang akan dipilih. Untuk metode rawai/long line sebaiknya pada kedalaman perairan 2-15 m

- Suhu umumnya berdampak langsung pada proses fisiologis tanaman atau efek tidak langsung melalui lingkungan setempat (Parenrengi dkk., 2012). Suhu yang baik berkisar antara 20-30 C (Surono dkk., 2008; Anggadiredja dkk., 2006) dengan aktifitas fotosintesis tertinggi terjadi pada suhu 23-34 C (Lideman dkk.,2014)

- Pertumbuhan yang baik terjadi pada siklus 12:12 (terang:gelap) pada intensitas cahaya sekitar 6000 lux (Parenrengi dkk., 2012). Air yang keruh biasanya mengandung lumpur yang dapat menghalangi tembusnya cahaya di dalam air, dan dapat menimbun permukaan thallus, sehingga akan mengganggu pertumbuhan dan perkembanganya (Puja dkk., 2008). Jarak pandang dengan menggunakan alat sechidisk sebaiknya mencapai 2-5 m (Parenrengi $d k k$., 2012).
- pergerakan air berfungsi menghadirkan nutrisi yang baru yang akan didifusi melalui dinding thallusnya (Sudariastuti, 2011), membersihkan tanaman, menyingkirkan sisa-sisa metabolisme, membantu pengudaraan, merangsang pertumbuhan tanaman melalui gaya/kekuatan hidrolik gerakan air, dan mencegah adanya fluktuasi suhu air yang besar (Surono dkk., 2009).

- Hidayat (1990) dalam Puja dkk. (2008) dan Anggadiredja dkk. (2006) menyatakan bahwa kecepatan arus yang baik untuk budidaya adalah 20$50 \mathrm{~cm} /$ detik. Parenrengi dkk. (2012) menjabarkan bahwa indikator suatu lokasi memiliki arus yang baik dapat dilihat dari tumbuhnya karang lunak dan padang lamun yang bersih dari kotoran dan cenderung miring ke satu arah. Semakin tinggi arus, laju pertumbuhan semakin tinggi namun masih dalam toleransi ketahanan bibit dan peralatan tidak rusak atau patah.

b. Faktor Kimia

- Salinitas adalah konsentrasi seluruh larutan garam yang diperoleh dalam air laut (Kordi dan Tanjung, 2007). E. cottonii adalah rumput laut yang bersifat stenohaline. Salinitas yang baik berkisar antara 28-35 g/l (Surono dkk., 2009). Untuk nilai optimum salinitas adalah 33 g/l (Puja dkk., 2008). Oleh karena itu, lokasi budidaya sebaiknya jauh dari sumber air tawar seperti muara sungai karena dapat menurunkan salinitas (Anggadiredja dkk., 2006)

- $\mathrm{pH}$ atau derajat keasaman merupakan logaritma dari kepekaan ion-ion hidrogen yang terlepas dalam suatu cairan. Semakin banyak kandungan $\mathrm{CO} 2$ dalam perairan akan menyebabkan $\mathrm{pH}$ air turun (Kordi dan Tanjung, 2007). pH yang ideal untuk pertumbuhan rumput laut berkisar antara 7,3-8,2 (Surono dkk.,2008)

- lokasi penanaman harus menghindari muara sungai karena merupakan tempat yang sangat rentang dengan pencemaran baik yang berasal dari industri maupun rumah tangga. Pencemaran logam berat cadmium yang diijinkan berkisar antara 0,01$0,02 \mathrm{ppm}$. 


\section{Hama dan Penyakit}

Hama rumput laut umumnya merupakan organisme laut yang hidup dengan rumput laut sebagai makanan utamanya atau sebagian masa hidupnya memakan rumput laut. Hama dapat menimbulkan kerusakan pada tanaman budidaya seperti tanaman terkelupas, patah atau habis dimakan (Surono dkk.,2009). Hama dikelompokkan menjadi dua kelompok yakni hama mikro (micro grazer) dan hama makro (makro grazer) (Parenrengi dkk., 2012).

Kurniastuti dkk. (2008) menjabarkan bahwa hama mikro merupakan organisme laut yang umumnya berukuran panjang $>2 \mathrm{~cm}$, hidup menempel pada thallus tanaman rumput laut dan biasanya tidak tampak pada thallus yang sehat. Hama mikro meliputi:

\section{a. Larva bulu babi (Tripneustes)}

Organisme ini berbentuk planktonik, melayang-layang di air kemudian menempel di rumput laut. Organisme ini menutupi permukaan thallus dan menyebabkan thallus berwarna kuning lalu mati.

\section{b. Larva teripang (Holothuria sp.)}

Larva teripang merupakan organisme planktonis yang menempel dan menetap pada thallus rumput laut. Larva kemudian tumbuh besar. Larva teripang yang sudah besar memakan thallus rumput laut.

Sedangkan hama makro adalah hama dengan ukuran relatif besar pada lokasi budidaya. Beberapa hama makro yang sering ditemui adalah: ikan baronang (Siganus sp.), bintang laut (Protoneustes nodosus), bulu babi (Diadema), bulu babi duri pendek (Tripneustes sp.) dan penyu hijau (Chelonia midas) (Surono dkk., 2008). Baronang merupakan hama yang menimbulkan kerusakan terbesar karena merusak dengan cara memakan bagian luar rumput laut dan menyisakan kerangkanya saja. Akibatnya, rumput laut mati dalam beberapa hari. Serangan ini terjadi secara musiman saat musim benih. Di Bali, Serangan ikan baronang terjadi pada awal musim angin Timur, yaitu bulan April.

Parengrengi $d k k$. (2012) menyarankan upaya pengendalian hama berupa:

a. Lokasi yang dipilih bukan merupakan habitat populasi endemik hama. b. Melakukan penanaman secara serentak dan meluas sampai titik jenuh hama tidak sebanding dengan biomass dari produksi total.

c. Menggunakan jaring sebagai pagar atau pembungkus pada daerah tertentu misalnya pada produksi benih untuk menghalangi masuknya hama besar.

d. Menangkap hama ikan yang biasanya mengganggu. Ikan herbivor (seperti baronang) yang menjadi hama dapat dimanfaatkan sebagai ikan konsumsi.

e. Apabila hama telah merajalela dan tidak dapat diatasi, maka rumput laut sebaiknya segera dipanen atau dipindahkan dan/atau menggantinya dengan bibit yang sehat pada saat musim hama telah berlalu.

Penyakit rumput laut dapat didefinisikan sebagai suatu gangguan fungsi atau terjadinya perubahan anatomi atau struktur yang abnormal. Misalnya adanya perubahan dalam laju pertumbuhan dan penampakan seperti warna dan bentuk. Perubahan ini pada akhirnya berpengaruh terhadap produktifitas hasil (Surono dkk., 2009).

Faktor lain disebabkan oleh adanya perubahan faktor-faktor lingkungan dan adanya interaksi antara faktor lingkungan (suhu, kecerahan, salinitas, dll) dengan jasad pathogen (organisme yang berperan sebagai penyebab penyakit).

Penyakit ice-ice (sebagian orang menyebutnya sebagai white spot) merupakan kendala utama budidaya rumput laut $E$. cottoniii. Gejala yang ditimbulkan antara lain: pertumbuhan yang lambat, terjadinya perubahan warna thallus menjadi pucat atau warna tidak cerah, dan sebagian atau seluruh thallus pada beberapa cabang menjadi putih dan membusuk (Parenrengi dkk., 2012). Adanya kotoran yang melekat pada thallus juga dapat menyebabkan penyakit ice-ice. Thallus yang tertutup kotoran tidak dapat menerima cahaya matahari sehingga pertumbuhannya terganggu dan terserang penyakit (Surono dkk., 2009)

\section{Panen dan Pasca Panen}

Kualitas rumput laut tidak hanya dipengaruhi teknik budidaya saja melainkan juga umur tanaman, cara panen dan keadaan cuaca saat panen (Anggadireja dkk. 2006). Beberapa hasil penelitian menunjukkan bahwa budidaya $E$. cottonii pada umur 45 hari memiliki kandungan karaginan $47 \%$ dan selanjutnya hanya 
terjadi peningkatan kadar karaginan yang tidak signifikan.

Panen sebaiknya dilakukan pada pagi hari supaya rumput laut yang dipanen dapat dijemur terlebih dahulu sebelum disimpan. Hal ini bertujuan untuk mengurangi kerusakan kualitas sebelum dijemur kembali pada keesokan harinya (Anggadiredja dkk., 2006). Selain itu, Runtuboy dkk. (2008) menambahkan jika penjemuran dilakukan pada cuaca cerah maka mutu rumput laut dapat terjamin. Sebaliknya, jika panen dan penjemuran dilakukan pada saat cuaca mendung, akan terjadi proses fermentasi pada rumput laut tersebut yang menyebabkan mutunya tidak terjamin.

Parenrengi dkk. (2012) menguraikan bahwa cara panen dapat dilakukan secara selektif atau parsial (pruning) dan keseluruhan (full harvest). Panen selektif dilakukan dengan memotong tanaman secara langsung tanpa melepaskan ikatan dari tali ris. Keuntungan cara ini adalah penghematan tali rafia pengikat rumput laut namun memerlukan waktu kerja yang relatif lama. Pemotongan tanaman sebaiknya menggunakan alat pemotong yang tajam agar tidak merusak jaringan thallus sehingga akan tumbuh percabangan baru yang baik. Panen selektif sebaiknya tidak dilakukan lebih dari tiga kali, setelah itu dilakukan panen secara keseluruhan. Hal ini disebakan karena pangkal thallus rumput laut yang tersisa semakin tua sehingga pertumbuhan cenderung lambat.

Parenrengi dkk. (2012) menjelaskan bahwa cara penanganan pasca panen termasuk penjemuran juga sangat menentukan mutu hasil produksi. Menurut Teurupun $d k k$. (2013) penjemuran bertujuan untuk memperoleh tingkat kadar air hingga batas terkecil untuk mengurangi pertumbuhan mikroorganisme. Salah satu kerusakan secara mikrobiologis yang ditemukan pada produk E. cottonii kering adalah keberadaan kapang. Kapang dapat memproduksi zat kimia yang bersifat racun yaitu mikotoksin. Jenis kapang yang ditemukan yaitu Fusarium sp. dan Penicilium sp.

\section{Analisis Finansial}

Komponen utama finansial meliputi biaya investasi, biaya tetap, biaya tidak tetap dan pendapatan. Biaya investasi dapat pula diartikan penanaman modal (baik fisik maupun non-fisik) termasuk membeli asetaset yang dibutuhkan. Jangka waktu investasi biasanya lebih dari satu tahun (Kasmir dan Jakfar, 2009). Biaya tetap atau disebut juga sebagai biaya kapasitas, yaitu biaya yang lahir karena menunjang kegiatan operasi pada suatu kapasitas tertentu bagi kegiatan- kegiatan, tidak tergantung kepada perubahan tingkat kegiatan dalam menghasilkan keluaran atau produk di dalam interval tertentu dan bersifat tetap jumlahnya (Prawironegoro dan Purwanti, 2009; Umar, 2005).

Biaya variabel adalah biaya yang berhubungan langsung dengan volume kegiatan sehingga berubah-ubah sesuai dengan perubahan tingkat produksi. Umar (2005) menyatakan bahwa pendapatan adalah seluruh unit yang diperoleh dan dinilai dalam rupiah. Dalam perhitungan pendapatan dapat dibedakan menjadi dua bagian yaitu pendapatan kotor (marginal) dan pendapatan bersih (keuntungan/laba). Pendapatan marginal adalah seluruh penerimaan dikurangi biaya tetap dan biaya tidak tetap.

Laba/rugi adalah aspek yang menunjukkan jumlah pendapatan yang diperoleh dan biaya-biaya yang dikeluarkan dalam suatu periode tertentu (Kasmir dan Jakfar, 2009). Dapat juga diartikan sebagai selisih antara pendapatan total dan biaya total (Widodo dan Syukri, 2005)

Profitability Indeks atau Benefit and cost ratio (Kasmir dan Jakfar, 2009) merupakan rasio atau perbandingan antara jumlah nilai sekarang arus kas selama umur ekonomisnya dan pengeluaran awal proyek (Subagyo, 2007). B/C Ratio menggunakan konsep dasar yang tidak memperhitungkan time value of money, menitik beratkan pada masalah accounting dan tidak memperhatikan cash flow dan investasi yang bersangkutan, pendekatan pada waktu jangka pendek, tidak memperhitungkan penjangnya waktu investasi, sederhana, dan biasanya digunakan pada siklus usaha dibawah 1 tahun. Kriteria kelayakan apabila hasil lebih dari $(>) 1$ atau sama dengan $(=) 1$ berarti dapat diterima karena setiap rupiah yang diinvestasikan akan menghasilkan satu rupiah. Namun apabila hasilnya sama dengan (=) 1 maka usaha tersebut berada di titik impas, sehingga hasil harus melebihi satu untuk memperoleh keuntungan (Sumardika, 2013) 
Break even point atau titik impas, oleh Umar (2005) disebut juga dengan istilah pulang pokok, adalah tingkat produksi dimana usaha mengalami kondisi tidak untung atau tidak rugi. BEP tersusun atas dua komponen yaitu BEP unit dan BEP nominal. BEP digunakan untuk mempelajari atau mengetahui hubungan antara biaya variabel, biaya tetap, tingkat keuntungan dan volume kegiatan/produksi. Sehingga BEP disebut juga sebagai teori Cost-Profit-Volume Analysis (CPV).

Payback periode yaitu suatu periode yang diperlukan untuk menutup kembali pengeluaran-pengeluaran investasi atau panjangnya waktu yang diperlukan untuk mengembalikan investasi yang ditanam (Sumardika, 2013). Kriteria kelayakan dinilai layak apabila nilai PP lebih pendek dari usia ekonomis dan dinilai tidak layak apabila PP lebih lama dari usia ekonomis (Subagyo, 2007).

ROI disebut juga ROA (Return on Asset) adalah tingkat pengembalian investasi atau asset yaitu membandingkan hasil usaha yang diperoleh dari operasi perusahaan atau nilai keuntungan yang diperoleh dari sejumlah modal. Nilai ini dapat digunakan untuk mengetahui efisiensi penggunaan modal (Widodo dan Syukri, 2005).

\section{METODOLOGI PENELITIAN}

\section{Waktu dan Tempat}

Penelitian dilaksanakan pada tanggal 1 September 2016 sampai 30 Oktober 2016 di Kelompok Usaha Bersama Mitra Bahari Desa Tanjung, Pademawu, Pamekasan, Madura. Desa Tanjung merupakan wilayah yang memiliki tingkat curah hujan rendah yaitu $1573 \mathrm{~mm}$ atau 13,6 mm/hari pada musim penghujan. Musim hujan relatif lebih singkat dibandingkan dengan daerah lain yaitu hanya sekitar tiga sampai empat bulan saja. Suhu rata-rata wilayah ini adalah $26,9^{\circ} \mathrm{C}$.

\section{Alat dan Bahan}

Peralatan yang digunakan selama praktik budidaya rumput laut meliputi thermometer, secchi disk, topdal, refraktometer, water level, kuas, palu, gunting, timbangan duduk, penggaris, millimeter blok, jangka sorong, tali polyethylene, pisau, bambu, jangkar, bandul, pancong, pelampung unit, terpal, pelampung, jaring, perahu, bak, timbangan gantung, timbangan duduk, alat panen (pengurut), sarkot, pengepresan, penjemuran dan parapara.

Bahan yang digunakan selama praktik budidaya rumput laut meliputi $\mathrm{pH}$ paper, cat, paku, sikat, bibit, karung, jarum, rafia, bensin dan oli.

Metode pengumpulan data yang digunakan dalam penelitian adalah metode survey / observasi pola magang dengan mengikuti semua kegiatan yang terkait dengan budidaya rumput laut ( $E$. cottonii) dengan metode jalur di Kelompok Usaha Bersama Mitra Bahari. Data yang dikumpulkan berupa data primer dan data sekunder.

Data primer diperoleh dari pengamatan dan partisipasi langsung pada kegiatan pemilihan lokasi, pengadaan dan pemilihan bibit, monitoring pertumbuhan, pengendalian hama dan penyakit, panen dan pasca panen, pengamatan kualitas air dan finansial budidaya rumput laut. Sedangkan data sekunder diperoleh dari wawancara dan data dari instansi terkait (penggunaan perairan, sejarah dan keanggotaan KUB, tenaga kerja, serta permasalahan budidaya).

\section{Metode Analisis Data}

Metode analis data menggunakan metode analisis secara diskriptif dan kuantitatif. Metode deskiptif dilakukan dengan menjelaskan dan melakukan pemaparan kegiatan yang dilakukan selama praktik dari mulai persiapan hingga pasca penen. Hasil praktik tersebut ditelaah dan dipadukan dengan literatur. Metode kuantitatif digunakan untuk menghitung pertumbuhan rumput laut dan finansial budidaya. Data primer diperoleh dari satu kali siklus budidaya (45 hari). sedangkan data sekunder diperoleh dari siklus-siklus sebelumnya. Data finansial yang adiambil adalah biaya investasi, biaya operasional (biaya tetap dan biaya tidak tetap), serta pendapatan. Selanjutnya analisa dihitung menggunakan rumus-rumus yang sesuai perhitungan.

\section{Metode Pengolahan Data}

a. Pertumbuhan rumput laut

$$
G=\left\{\left(\frac{W t}{W o}\right)^{\frac{1}{T}}-1\right\} x 100 \%
$$




$$
\begin{aligned}
\mathrm{G} & =\text { laju pertumbuhan harian (\%) } \\
\mathrm{Wo} & =\text { bobot rata-rata awal }(\mathrm{g}) \\
\mathrm{Wt} & =\text { bobot rata-rata akhir }(\mathrm{g}) \\
\mathrm{T} & =\text { umur tanaman }
\end{aligned}
$$

b. Kecepatan arus

$$
\text { Kecepatan }=\frac{\text { jarak }(\mathrm{cm})}{\text { waktu }(\text { detik }}
$$

c. Kecerahan

$$
\operatorname{Kecerahan}(m)=\frac{m 1-m 2}{2}
$$

$\mathrm{m} 1=$ kedalaman secchi disk tidak tampak

$$
\begin{aligned}
\mathrm{m} 2= & \text { kedalaman secchi disk tampak } \\
& \text { pertama kali }(\mathrm{m})
\end{aligned}
$$

\section{Metode Analisa Finansial}

a. Laba/rugi

laba rugi = pendapatan - biaya operasional

b. $\mathrm{B} / \mathrm{C}$ ratio

$$
\frac{B}{C} \text { ratio }=\frac{\text { pendapatan }- \text { biaya operasional }}{\text { biaya operasional }}
$$

c. BEP

$$
B E P=\frac{\text { biaya tetap }(R p)}{\text { harga }(\mathrm{kg})-\text { biaya variabel }(\mathrm{kg})}
$$

d. Payback Period

$$
\text { Payback period }=\frac{\text { nilai investasi }}{\text { laba }+ \text { penyusutan }} \times 1 \text { th }
$$

e. Return on Investment

$$
\text { RoI }=\frac{\text { Laba usaha }}{\text { Modal produksi }}
$$

\section{HASIL DAN PEMBAHASAN}

Lokasi budidaya rumput laut $E$. cottonii di KUB Mitra Bahari berada di perairan Selat Madura dengan dasar pasir berlumpur dan perairanya terlindung tanjung. Parameter kulaitas air di lokasi penelitian ditunjukkan oleh tabel 2.

Tabel 2. Parameter Kualitas Air

\begin{tabular}{|l|l|l|}
\hline Parameter & $\begin{array}{l}\text { Nilai } \\
\text { optimum }\end{array}$ & Nilai lokasi \\
\hline $\mathrm{pH}$ & $7,0-8.5$ & $6,5-8$ \\
\hline suhu & $26-32^{\circ} \mathrm{C}$ & $28-33^{\circ} \mathrm{C}$ \\
\hline salinitas & $28-34 \mathrm{~g} / \mathrm{L}$ & $30-33 \mathrm{~g} / \mathrm{L}$ \\
\hline kecerahan & $2-5 \mathrm{~m}$ & $0,43-1,73 \mathrm{~m}$ \\
\hline $\begin{array}{l}\text { Kecepatan } \\
\text { arus }\end{array}$ & $\begin{array}{l}20-40 \\
\mathrm{~cm} / \mathrm{dtk}\end{array}$ & $7-31 \mathrm{~cm} / \mathrm{dtk}$ \\
\hline
\end{tabular}

Bibit yang berasal dari lokasi setempat, penanganan berupa panen dan pengikatan dilakukan dihari yang sama. Sedangkan untuk bibit yang berasal dari Sumenep diangkut

Lokasi budidaya berada $295 \mathrm{~m}$ dari pasang tertinggi. Namun, dari data scoring sheet penilaian lokasi yang dilakukan, skor yang diperoleh sebanyak 66 atau berada pada kategori batas diterima. Hal itu berarti bahwa dibutuhkan modifikasi untuk parameter yang kurang sesuai. Parameter faktor ekologis yang belum memenuhi nilai optimum menurut SNI (8228.2:2015) meliputi pH, suhu, kecepatan arus dan kecerahan. Sedangkan dasar perairan dan kecerahan juga belum sesuai dengan pendapat Parenrengi $d k k$. (2012) yang menyatakan dasar perairan yang ideal berupa pecahan karang dan pasir kasar serta nilai kecerahan 2-5 m.

Selain faktor diatas, ketersediaan bibit dapat digolongkan kontinyu karena dapat diperoleh dari pembibitan pada lokasi atau daerah luar yang tidak terlalu jauh. Lokasi juga bukan tempat berkumpul predator, sehingga aman untuk di jadikan tempat perkembangan rumput laut.

Sumber bibit yang digunakan berasal budidaya dari luar daerah yaitu daerah Sumenep, Madura (untuk penanaman ke-1) dan dari daerah setempat (untuk penanaman ke-2).

Bibit dipilih yang memiliki thallus rimbun, berwarna hijau cerah, bersih, tidak berpenyakit, tunas runcing, dan berumur 30 hari. Hal ini sesuai dengan SNI (7672:2011) yang menyatakan bahwa secara kuantitatif rumput laut berumur 25-30 hari, thallus minimal bercabang 3 , diameter thallus utama minimal $0,5 \mathrm{~cm}$ dan seragam, berat per rumpun 50-100 gram. Bibit yang sesuai dengan standar dapat dilihat pada Gambar 1.

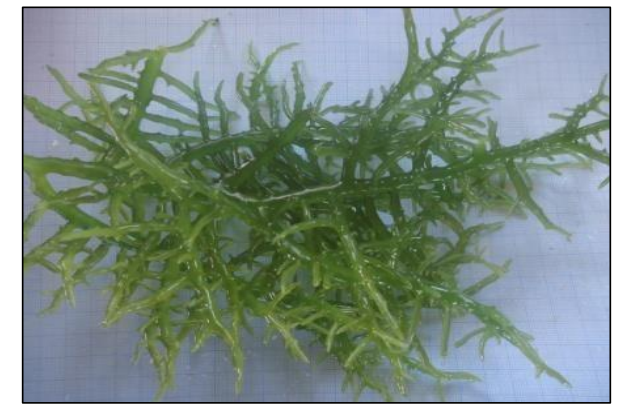

Gambar 1. Bibit yang akan ditanam 
menggunakan truk pada pagi hari sehingga menghindari intensitas panas yang tinggi. Sebanyak $4.950 \mathrm{~kg}$ bibit dimasukkan ke dalam 99 karung dengan kuantitas rata-rata $50 \mathrm{~kg}$ per karung untuk menjaga menghindari kerusakan rumput laut, paparan sinar matahari langsung dan menjaga kelembapan rumput laut.

Pengikatan dilakukan di ruang terbuka berukuran $4 \times 12 \mathrm{~m}$ di tepi pantai yang terlindung dari matahari. Pengikatan pada pennaman pertama dilakukan selama 5 jam yaitu mulai pukul 12.00 WIB sampai pukul 17.00 WIB dengan mengerahkan 90 orang tenaga kerja. Untuk pengikatan dan penanaman kedua dilakukan selama 3 jam dengan jumlah tenaga sebanyak 18 orang.

Tali ris yang digunakan sepanjang 17 meter dengan jumlah 35 tali per unitnya. Dalam satu tali ris terdapat 125 tali titik sehingga jarak rata-rata antar titik yaitu 15 $\mathrm{cm}$

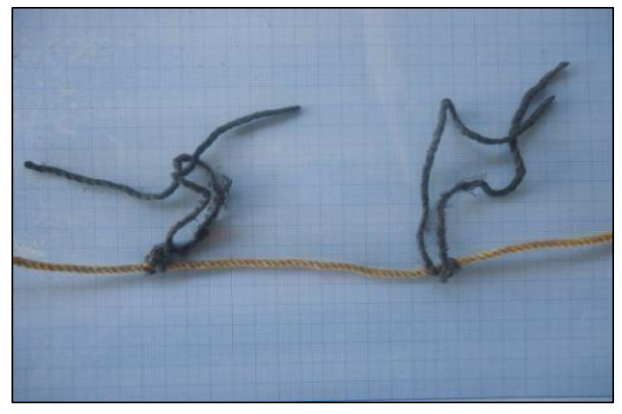

Gambar 2. Jarak antar tali titik

Setelah pemotongan bibit, selanjutnya dilakukan pengikatan bibit pada tali titik. Pada satu tali titik, terdapat dua tali terpisah dengan panjang masing-masing sisi tali titik adalah $18 \mathrm{~cm}$. Setiap tali diisi satu bibit sehingga pada titik tersebut (dua sisi tali) berat bibit menjadi $40 \mathrm{gr}-80 \mathrm{gr}$. Berat tersebut kurang sesuai dengan SNI (7673.2:2011) yang menyarankan berat bibit per titik $50 \mathrm{gr}-100 \mathrm{gr}$. Semakin kecil bibit, kompetisi nutrisi juga semakin rendah sehingga perolehan nutrisi lebih tinggi yang berimbas pada laju pertumbuhan yang lebih baik. Hal ini sesuai dengan Irawati (2015) yang menyatakan bahwa laju pertumbuhan spesifik dan laju pertumbuhan mutlak tertinggi ada pada bibit dengan berat terkecil. Namun, semakin kecil ukuran bibit akan berdampak pada jumlah panen per unit.
Pengikatan menggunakan metode pengikatan loop panjang seperti dapat dilihat pada Gambar 3. Kelebihan loop panjang adalah pergerakan yang lebih fleksibel dan lebih mudah dalam pengikatan namun rawan terbelit saat arus besar. Hal tersebut sesuai dengan Parenrengi $d k k$. (2012) yang menyatakan bahwa loop pendek pergerakanya lebih kaku

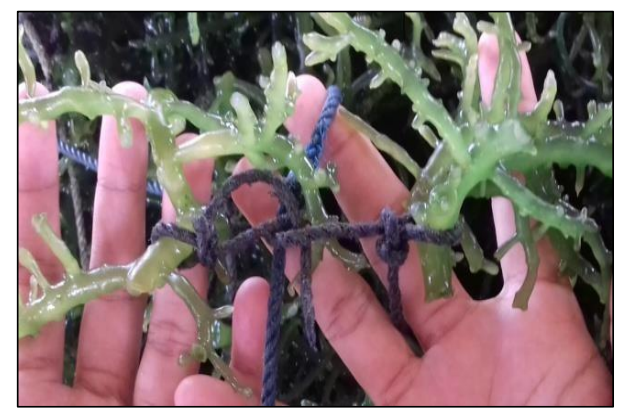

Gambar 3. Pengikatan dengan menggunakan loop panjang

Tali ris yang telah selesai diikati bibit, selanjutnya diangkut ke tempat bambu telah dijangkarkan yaitu di tempat terendam air laut. Hal ini sesuai dengan Sudrajad (2008) yang menyarankan penanaman segera setelah pengikatan agar bibit masih segar dan tidak lama terkespos di darat. Pengikatan tali ris yang dilakukan, disertai dengan pengikatan pelampung berupa botol-botol plastik. Botolbotol plastik selain berfungsi sebagai pelampung, juga berfungsi sebagai pengatur kedalaman. Apabila kedalaman pada penanaman rumput laut perlu ditambah, maka dilakukan pengisian air untuk lebih memberatkan tali ris sehingga posisi penanaman lebih turun.

Setelah dilakukan penanaman, dilanjutkan pemeliharaan rumput laut. Pemeliharaan dilakukan dua kali seminggu sehingga belum sesuai SNI (7673.2:2011) bahwa pengontrolan minimal tiga kali seminggu. Bahkan Santoso dan Nugraha (2008) menyarankan untuk melakukan pembersihan setiap hari. Pemeliharaan dilakukan dengan membersihkan rumput laut dari dari hewan maupun tanaman pengganggu, membersihkan lumpur yang menempel, menyulam dan menghilangkan bagian yang terjangkit penyakit

Pada pemeliharaan dilakukan juga monitoring pertumbuhan yang diukur setiap satu minggu sekali dengan letak titik sampling sebanyak 3 titik. 
Pada masa pemeliharaan, ada beberapa gangguan budidaya yang berasal dari hama dan penyakit. Hama yang ditemukan selama budidaya adalah baronang (Siganus sp.) dan Sargassum sp. sedangkan penyakit yang ditemukan berupa ice-ice.

Panen dilakukan sebanyak dua kali selama praktik yaitu panen bibit dan panen konsumsi. Untuk panen bibit, rumput laut segera diikat kembali.

Panen bibit dilakukan pada usia pemeliharaan 30 hari sedangkan rumput laut konsumsi dipanen pada usia pemeliharaan 45 hari. Panen pada usia 45 hari dilakukan untuk memperoleh kadar karaginan terbaik karena setelah usia tersebut, penambahan karaginan tidak lagi maksimal sehingga hanya akan memperlama panen. Hal tersebut serupa dengan pendapat Parenrengi dkk. (2012) bahwa kandungan E.cottonii pada usia 45 hari adalah $47 \%$ dan selanjutnya hanya terjadi peningkatan yang tidak signifikan.

Total hasil panen basah adalah $7.737 \mathrm{~kg}$ sedangkan ketersediaan para-para hanya ada 21 buah (kapasitas $200 \mathrm{~kg}$ rumput laut basah per para-para). Pada hari selanjutnya setelah sebagian rumput laut yang sudah dikeringkan digabungkan, para-para digunakan untuk menjemur sebagian yang lain. Penjemuran dilakukan di atas para-para dengan melakukan penutupan menggunakan terpal di malam hari. Cara tersebut membuat rumput laut terpapar angin di malam hari sehingga mempercepat pengeringan dan lebih bersih bila dibandingkan dengan penjemuran di permukaan tanah. Hal tersebut sesuai dengan SNI (2690:2015) bahwa pengeringan dilakukan dengan menyusun di atas para-para atau digantung.

Rumput laut dijemur selama empat hari dengan pembalikan setiap pukul 12.00 WIB dan 17.00 WIB hingga terlihat kristal-kristal garam di permukaanya. Hal ini sesuai dengan Surono dkk. (2009) bahwa ciri rumput laut yang sudah kering yaitu berwarna ungu keputihan dilapisi kristal garam. Hasil kering yang diperoleh seberat $1.105 \mathrm{~kg}$ (26 karung) sehingga perbandingan berat basah dan berat kering yaitu 1:7.

Perhitungan pendapatan petani rumput laut dapat dilihat sebagai berikut:

a. KUB

Pendapatan kotor $=$ Rp 278.409.692
Pendapatan bersih $=$ pendapatan-pajak $=278.409 .692-(1 \% \mathrm{x}$ 278.409 .692 $=275.625 .595$

Jadi pendapatan bersih sebesar Rp. $275.625 .595,00$

b. Laba/rugi

Laba/rugi = pendapatan- biaya operasional = pendapatan-(biaya tetap+biaya tidak tetap)

$=$ Rp275.625.595-

(19.027.946+193.745.267) $=\operatorname{Rp} 62.852 .382$

Artinya, usaha kelompok ini memiliki selisih pendapatan dan biaya operasiona; sebanyak Rp 62.852.382,00

c. $\mathrm{B} / \mathrm{C}$ ratio

$\frac{B}{C}$ ratio $=\frac{\text { pendapatan }- \text { biaya operasional }}{\text { biaya operasional }}$

$\frac{B}{C}$ ratio $=\frac{\text { pendapatan }}{\text { biaya tetap }+ \text { biaya tidak tetap }}$

$\frac{B}{C}$ ratio $=\frac{278.409 .692}{17.567 .946+195.205 .267}$

$=1,3$

Artinya, 1 rupiah yang diivestasikan KUB menghasilkan 1,3 rupiah

d. BEP

$$
\begin{aligned}
& B E P=\frac{\text { biaya tetap }(R p)}{\text { harga }(\mathrm{kg})-\text { biaya variabel }(\mathrm{kg})} \\
& B E P=\frac{17.567 .946}{8000-5590} \\
& B E P=7290
\end{aligned}
$$

Artinya, usaha mencapai titik impas pada hasil $\mathrm{Rp} 7.290 / \mathrm{kg}$

e. Payback Period

Payback period $=\frac{\text { nilai investasi }}{\text { laba }+ \text { penyusutan }} \times 1$ th

Payback period

$=\frac{162.496 .292}{62.852 .382+15.867 .946} \times 1 \mathrm{th}$

$=2,1$ tahun

Artinya, waktu untuk mengembalikan investasi yang ditanam adalah 2 tahun 1 bulan, 6 hari

f. Return of investment

$R o I=\frac{\text { Laba usaha }}{\text { Modal produksi }}$ 


$$
\begin{aligned}
\text { RoI } & =\frac{62.852 .382}{162.496 .292} \\
& =40 \%
\end{aligned}
$$

Artinya, tingkat pengembalian investasi usaha adalah $40 \%$

\section{SIMPULAN DAN SARAN}

\section{Simpulan}

Setelah melakukan penelitian di KUB Mitra Bahari, maka dapat ditarik kesimpulan:

1. Teknik budidaya rumput laut (Eucheuma cottonii) meliputi:

a. Pemilihan lokasi belum baik karena masih ada parameter kualitas air yang kurang sesuai dengan kebutuhan rumput laut

b. Pengadaan dan pemilihan bibit sudah dilakukan dengan baik namun terkendala lokasi bibit yang tidak dari daerah budidaya

c. Pengikatan dan penanaman bibit sudah dilakukan dengan baik namun terdapat berat bibit kurang dari standard SNI 50-100 gr.

d. Pertumbuhan kurang baik karena $<3 \%$.

e. Kualitas air kurang sesuai untuk pertumbuhan rumput laut dengan $\mathrm{pH}$ 6,5 -8, suhu 28-33 $\mathrm{C}$, salinitas $30-33$ $\mathrm{g} / \mathrm{l}$, kecerahan 43-173 cm, dan kecepatan arus $7-31 \mathrm{~cm} /$ detik

f. Hama dan penyakit belum dikendalikan dengan baik karena masih ditemukan hama berupa Sargassum sp. dan ikan baronang (Siganus sp.) serta penyakit ice-ice.

2. Analisa KUB Mitra Bahari diperoleh sebagai berikut:

a. Pendapatan Rp 275.625.595

b. Rugi/laba dengan nilai laba $\mathrm{Rp}$ 62.852 .382

c. Benefit/cost Ratio (B/C Ratio) adalah 1,3

d. Break Even Point (BEP) unit adalah $7.290 \mathrm{~kg}$ dengan BEP rupiah $\mathrm{Rp}$ 58.316 .833

e. Payback Periode (PP) adalah 2 tahun 1 bulan 6 hari

f. Return on Investment (ROI) adalah $40 \%$

\section{Saran}

Adapun saran untuk budidaya rumput laut KUB Mitra Bahari antara lain:

1. Memindahkan lokasi penanaman ke lokasi yang lebih layak

2. Menyesuaikan ukuran bibit dengan standard yaitu 50-100 gr per titik

3. Merenggangkan jarak antar titik hingga 25-30 cm

4. Melakukan monitoring tidak hanya \pm 3 hari sekali, namun setiap hari

\section{DAFTAR PUSTAKA}

Arisandi, Apri dan Akhmad Farid. 2014. Dampak Faktor Ekologis terhadap Sebaaran Penyakit Ice-ice. Jurnal Kelautan. Vol 7. Hal 20-25.

Parenrengi, Andi, Rahman Syah dan Emma Suryati. 2012. Budi Daya Rumput laut Penghasil karaginan (Karaginofit). Badan Penelitian Pengembangan Kelautan dan Perikanan Kementerian Kelautan dan Perikanan Republik Indonesia. Jakarta

Prabowo, Guntur dan Moch. Farchan. 2008. Teknik Budidaya Rumput Laut. BAPPL STP Serang. Serang

Purbiantoro, Wahyu, Wida Lesmanawati dan hairati Arfah. 2013. Jenis dan Pengaruh keberadaan Alga Filamen pada Kegiatan Budidaya Eucheuma cottonii di Perairan Teluk Kotania, Seram. Jurnal Sains Terapan Edisi III. Vol 3. Hal 9-18

Sunaryat, Hermo Wijoyo dan Istiqomah. 2008. Teknologi Budidaya Rumput Laut (Kappaphucus alvarezi). Balai Besar Pengembangan Budidaya Laut Lampung. Lampung

Surono, Agus, Edward Danakusumah Sulisttijo, A. Zatnika. 2009. Profil Rumput Laut Indonesia. Direktorat Jenderal Perikanan Budidaya Departemen Kelautan dan Perikanan. Jakarta 